Cypriote pottery of the Bronze age. An important find consisted of portions of two literary texts, which, as the oldest cuneiform documents as yet found in northern Syria, may be expected to yield results of considerable historical interest. The date of the building can be fixed with tolerable accuracy, as information from the main excavation of the year, which was on a much larger scale, indicates consecutive periods ranging from the twelfth back to the sixteenth or seventeenth century B.c. Here, below cremation graves, was found a house, which on the evidence of Mycenæan pottery belongs to the thirteenth or fourteenth century B.c. Inscribed tablets afford evidence of the existence of a royal library. In the fourth level, dated at the sixteenth century B.c., was found a house which in its details corresponds to the larger building previously described, and being characteristically Hittite, serves also to place the Hittite occupation of northern Syria at a much earlier date than hitherto accepted.

\section{Swanscombe Skull: Committee of Investigation}

THE character of the Swanscombe skull and the conditions of its discovery both in themselves and in relation to the Piltdown skull, suggested that a certain suspension of judgment was advisable for further consideration of the evidence, before accepting the find at its face value as inferred by Mr. A. T. Marston on his announcement of the find (see NATURE of October 19, 1935, p. 637 and August 1, 1936, p. 200). A report was also promised on the palæontological evidence, which clearly would have an important bearing on any conclusion to be drawn. So far, anthropologists, while admitting the importance of the discovery as reported by Mr. Marston, have been inclined to caution. An announcement, therefore, is welcome that the Royal Anthropological Institute has appointed a committee to investigate the evidence which Mr. Marston has collected, and to co-operate with him in the further investigation of the site. This committee consists of Mr. M. A. C. Hinton, keeper of zoology, British Museum (Natural History), (chairman), Mr. K. P. Oakley, Department of Geology, British Museum (secretary), Prof. P. G. H. Boswell, Imperial College of Science, London, Prof. W. E. Le Gros Clark, Department of Anatomy, University of Oxford, Mr. H. G. Dines, Geological Survey of Great Britain, Mr. C. F. C. Hawkes, Department of British Antiquities, British Museum, Prof. W. B. R. King, Department of Geology, University College, London, Mr. A. T. Marston, Dr. G. M. Morant, Galton Laboratory, University College, London, and Mr. S. Hazzledine Warren.

\section{The Empire Cotton Growing Corporation}

At a meeting of the Administrative Council of the Empire Cotton Growing Corporation held in Manchester on May 25, it was announced that the Corporation has recently acceded to a request from the Indian Central Cotton Committee that Dr. T. G. Mason should be permitted to spend some months in India to advise in connexion with an investigation into the causes of the periodic failure of the cotton crop in the Punjab. It was also reported that in letters that had been received from Prof. J. W. Munro, who is making a tour in Africa to advise the Corporation on its work on cotton insect pest control, he has written enthusiastically of the high quality of the work that was being carried out by the Corporation's staff, and recommended that it should continue to receive full support. An addition to the staff in Nyasaland may be necessary. It was naturally impossible to say whether it would prove possible to devise any practical measures for controlling these pests, but pests constituted the limiting factor in cotton-growing throughout considerable areas in Africa, and the Corporation should therefore leave nothing undone which might bring to light any information that might possibly lead to a reduction in the loss of crop thus caused.

\section{Genetic Theory and Practice in the U.S.S.R.}

IN a note on genetics in the U.S.S.R. (NATURE, 139,185 ; Jan. 30,1937 ), reference was made to the empirical work of Michurin on the hybridization of fruits, and his published work was said not to have been translated into any foreign language. Our attention had been directed to the fact that a translation, in an abridged form, is available for reference in the Bureau of Plant Genetics at Cambridge. The short published abstracts of the Bureau (Plant Breeding Abstracts, 5, 56, 376 and 7, 122) make the character of Michurin's work fairly clear. Like the recent work of Burbank in the United States, it belongs to the period of Kölreuter. It uses the assumptions and deals with the problems that were in favour in the late eighteenth century. Indifference to the refinements of later work has led Michurin, as it did Burbank, to somewhat fantastic conclusions in physiology and genetics. The reason for Michurin's indifference, however, is peculiar and significant. He states that the Mendelian principles are not in accordance with the dialectic of Engels, and must therefore be disregarded. It seems that Aristotelianism is appearing in a new quarter under a new guise.

\section{Mechanized Farming}

THE report on the discussions at the Oxford Conference on Mechanized Farming held in January last has been published. It contains the opening and concluding addresses given by Mr. C. S. Orwin and Mr. Roland Dudley respectively, and full accounts of the discussion that followed the papers dealing with tractor performance and row-crop cultivation, cultivations, the maintenance of fertility, grass drying and combine harvesting. Both the practical and scientific points of view are well represented and the publication is clearly a valuable complement to the papers themselves. The complete Proceedings of the Conference ( 2 vols.), which includes both the papers and discussions, may be obtained from the Conference Secretary, 10 Parks Road. Oxford, price 2s. 6d. post paid. 